\title{
The Basic Cycles of Vocational Training (BPT) in Spain: Stu- dent satisfaction and perceived benefit
}

\author{
Martínez-Carmona, M.J. ${ }^{*}$, Gil del Pino, C. ${ }^{2}$ and Álvarez-Castillo, J.L ${ }^{3}$ \\ 1 Department of Education, Faculty of Education Sciences, University of Córdoba, España \\ 2 Department of Education, Faculty of Education Sciences, University of Córdoba, España \\ 3 Department of Education, Faculty of Education Sciences, University of Córdoba, España \\ * Correspondence: mjmartinez@uco.es; https://orcid.org/0000-0002-6823-1281. Department of Education, Fac- \\ ulty of Education Sciences, University of Córdoba. Avda. San Alberto Magno s/n 14071 - Córdoba, España.
}

\begin{abstract}
:
This study aims to better understand students who attend the Basic Vocational Training Cycles (FPB) regarding the measures to ensure diversity. This quantitative research project approximates the perception of students concerning their passage through their previous studies and their satisfaction and goals after finishing the school year. The sample consists of 352 students from Cordoba (Spain). A questionnaire has been used which follows the CIPP model. After the exploratory factor analysis was completed with the different groups of items and their descriptive analysis, various tests were carried out to consider the hypotheses (Pearson's correlation $(r)$, one-factor analysis of variance and repeated ANOVA measures). The results indicate that the educational interest of the students is academic and professional. Likewise, there is no relationship detected between the appearance of socio-professional goals and average academic levels and the attributions with respect to repetitions of previous courses, although these goals vary depending on the satisfaction shown by the students with respect to the cycles. We conclude that the course of the FPB influences the adoption of decisions regarding academic-professional projects.
\end{abstract}

Keywords: Transition decisions, Secondary School, School tracks, Revealed students' preferences, Satisfaction, Quantitative method, Optimization.

\section{Introduction}

Permanent education does not express a long-term desire of the population but a present need [1,2]. The global market generates a degree of competitiveness and uncertainty characterized by the constant change of regulations worldwide. The objective is to adapt training to the market and companies, while also covering new sources of employment [3]. On the other hand, it is necessary to promote civic-social skills with methodological strategies and adjusted programs, aimed towards the transition to employment [4]. With this in mind, attractive, innovative and dynamic Vocational Education and Training (VET) is considered [5-9].

The current vision defended by various national and world bodies is that VET (Vocational Education and Training) is the method best adapted to the reality of the labor market and the needs of the world economic system. The aim is to be able to provide qualified and specialized personnel to the productive professional sectors and satisfy the demand for employment [10-12]. In this sense, a wide catalog of Training Cycles is made possible within various professional fields [9], each one specified in theoretical-practical 
contents that help the future worker develop specialized skills. Depending on the level of study required, these Cycles are divided into: Basic (BTP, in Spain, FPB), Middle Grade and Higher-Grade Vocational Training Cycles.

The Basic Cycles, the object of this study, grant the Basic Professional Title and in Spain they are offered on a compulsory and free basis. To promote them, the goal is to generate a culture of innovation and risk-taking [6] that encompasses all scales of the production system and society, especially in education and training. One of the European objectives is innovation, the axis of modernization of VET [13-16].

Organic Law 8/2013, of December 9, para la mejora de la calidad educativa (LOMCE), mentions how the rigidities of the system can be exclusive with a part of the student body because they have different interests from those set by the system itself [17-19]. Letting students follow different paths would help reduce school dropouts and improve personal and professional development. Basic Professional Training (BPT) is one possible option [20]. Historiographic synthesis studies [21] analyze the expression professional training and the variability of its interpretation, as well as its correlation and subordination to lifelong learning, according to a historical and comparative or international axis. From a technical-analytical approach to standardized mass production, typical of Taylorism and considered in the 1990s to be a sign of progress and growth [22], in which the ideal worker endured monotony and hard work, to the study of the Lean production [23], in which the worker has learned to adapt to the needs of production, education has played a fundamental role in adaptation. This eminently socializing character of the school drives the modernization of the search for a model with less youth unemployment [24]. We evoke Durkheim [25] in recalling that the purposes of education is to elicit physical, intellectual, and moral states demanded by political society - as a whole - and the specific environment it is specifically destined for.

For a student to be admitted to BPT, they must meet the following requirements simultaneously: be between fifteen and seventeen years old; have started Compulsory Secondary Education (ESO); be proposed by the teaching team for incorporation into a BPT cycle [19]. Its usual duration is two years.

Upon successful completion of the professional modules, the student obtains a Level 1 qualification from the National Catalog of Professional Qualifications [24] and the title of Basic Professional, which grants access to the Middle Degree training cycles, although it does not grant the ESO title, which requires an additional knowledge assessment [17].

\subsection{BPT student profile}

The United Nations Development Program [26] considers the vulnerability to marginalization of young people in the labor market due to unemployment, underemployment or precarious contracts [27]. Likewise, transitions during youth become uncertain, and the de-standardization of normalized models - of a more reliable and predictable nature - reveals the end of the linear cause-effect relationship, of a before and after model [27-30]. The EGRIS (European Group for Integrated Social Research) network assessed the unwanted effects of social exclusion and labor market policies for young people in Europe [31], with the participation of research teams from Denmark, Germany, Ireland, Italy, the Netherlands, Portugal, Spain and the United Kingdom. Research on youth and the labor market shows that many young people choose, or are forced to choose, educational options that do not lead to stable jobs or socially accepted status; others drop out or completely withdraw from the system, preferring a zero status in which they experience alienation and humiliation [28]. Various authors show us the possibility for youths to escape these closed circuits [8,32-35], discussing the need for positive experiences, the positive development of personal identity and the meaning of work as elements for optimization, issues of vital importance for BPT [36, 37].

In this regard, the research indicates that the current measures in place seeking diversity could lead to the exclusion of students rather than inclusion, as intended [38-40]. Other studies [41,42], reveal little collaboration between the teaching staff, the counselor 
and other members of the educational community in the implementation of the cycles. Its short duration results in the selection of incomprehensible content and objectives. Likewise, planning is usually short-term and adapted to the needs of the students, and must renounce interest in studies [43], because after the student's failure in the in the traditional system, they cannot offer more of the same [41,44,45]. Finally, taking into account that many of the students in the BPT program were guided unsuccessfully through Secondary Education, orientation and tutoring should be promoted by in BPT so that students can set goals and expectations $[45,46]$, according to the peculiarities of the context and of the students themselves [47, 48].

\section{Materials and Methods}

In a broad sense, this research is based on a rigorous and objective analysis of the educational situation [49]. We intend to learn about the educational reality for students in BPT. We highlight the following objectives: to learn about student experiences and perceptions concerning the courses not passed, show their satisfaction with BPT, and learn about their expectations after completion of their studies. The research design is flexible and will be adapted to the context. This study, from the rationalist paradigm and a quantitative perspective, is defined as descriptive, applied and evaluative.

The sample has been drawn from 27 Secondary Education centers in Cordoba (Spain) out of the 60 that offer BPT, with a total of 352 students surveyed during the 2016-2017 academic year.

In regard to personal and context data, the students are between 14 and 19 years old. $72.2 \%$ are men and $27.8 \%$ are women, a percentage comparable to that recorded in MECD and MEFP reports [14, 15]. The study covers the specialties: Office computing (n $=27)$, Administrative services $(n=46)$, Agro-gardening and floral compositions $(n=54)$, Electricity and electronics $(n=59)$, Kitchen and catering $(n=19)$, Hairdressing and aesthetics $(n=15)$, IT and communications $(n=81)$, Carpentry and furniture $(n=17)$, Domestic activities and building cleaning $(n=8)$, Vehicle maintenance $(n=19)$ and Food industries $(\mathrm{n}=7)$.

The instrument used is the questionnaire. Due to the limited existing studies in this area, it has become necessary to complete exploratory factor analyses with the groups of items that make up this tool, structured in blocks through the CIPP model (Stufflebeam), with the following scheme: Context or input, process and product. Open and closed Likert-type questions have been alternated with the possibility of answers ranging from 1 to 5, adding the option "I don't know/I don't answer" where appropriate.

The validity of the construct has been determined using exploratory factor analysis through the SPSS statistical program. To this end, the Bartlett sphericity test has been applied to each group of items, which made it possible to continue with the extraction of factors. The Kaiser-Meyer-Olkin sample adequacy measure has been taken into account to determine the acceptable degree of common variance between the items. The solution was rotated at the beginning with Varimax, but with those factors that were proven reliable and correlated significantly and with some intensity, the initial decision was reconsidered and an oblique rotation method was adopted (Oblimin with Kaiser normalization [delta $=0]$ ). The reliability of the survey and the various resulting factors was found by means of Cronbach's Alpha internal consistency analysis.

After the interpretation of those factors considered reliable and the high correlation between them, the functioning of the variables has been evaluated descriptively and we have proceeded to contrast the hypotheses raised with the predictive values through the Pearson correlation test $(r)$, one-factor variance analysis and, repeated ANOVA measures, based on their normal distribution and the type of variables analyzed in each case. For the latter analyses, the Kolmogorov-Smirnov statistical test was not chosen to determine if the data fit a normal distribution because ANOVA is considered a robust test by itself. The assumption of homoscedasticity has been previously verified in the Levene test. 


\section{Results}

The results shown below are divided by blocks: school records; attributions regarding repetitions of previous courses; current educational interest; satisfaction shown with respect to BPT cycles; goals after completing the cycle.

\subsection{School Records}

Descriptive data regarding the repetitions of students in previous courses are shown below (table 1).

Table 1. Repetitions of BPT students in Primary and Secondary Education

\begin{tabular}{|c|c|c|c|c|c|c|c|c|c|c|c|c|c|}
\hline \multicolumn{4}{|c|}{ Repetitions in Primary Education } & \multicolumn{4}{|c|}{ Repetitions in Secondary Education } & \multicolumn{6}{|c|}{ № Repetitions in Secondary Education } \\
\hline \multicolumn{2}{|c|}{ YES } & \multicolumn{2}{|c|}{$\mathrm{NO}$} & \multicolumn{2}{|c|}{ YES } & \multicolumn{2}{|c|}{$\mathrm{NO}$} & \multicolumn{2}{|c|}{1} & \multicolumn{2}{|c|}{2} & \multicolumn{2}{|c|}{$>2$} \\
\hline $\mathrm{n}$ & $\%$ & $\mathrm{n}$ & $\%$ & $\mathrm{n}$ & $\%$ & $\mathrm{n}$ & $\%$ & $\mathrm{n}$ & $\%$ & $\mathrm{n}$ & $\%$ & $\mathrm{n}$ & $\%$ \\
\hline 171 & 50.6 & 167 & 49.4 & 316 & 92.4 & 26 & 7.6 & 144 & 49 & 128 & 43.5 & 18 & 6.1 \\
\hline
\end{tabular}

About half of the students have repeated courses in primary $(\mathrm{N}=352)$, a figure that increases in Secondary $(92.4 \%, \mathrm{n}=316)$, in which $49 \%$ repeated once and $43.5 \%$ twice. The failure of these students in school is evident and it is essential that we review the attributions that the students in this regard, as detailed below.

\subsection{Attributions regarding repetitions of previous courses}

An exploratory factor analysis was carried out using principal component analysis. Bartlett's sphericity test showed a significant difference between the empirical correlation matrix and the identity matrix $\left(x^{2}[231]=1400.08, p<.001\right)$, which made it possible to continue with factor extraction. Likewise, the Kaiser-Meyer-Olkin measure of sampling adequacy reported an adequate degree of common variance between the items $(\mathrm{KMO}=.801)$.

The criterion of an eigenvalue greater than 1 was maintained, since it yields a solution of six fairly uniform factors in terms of explained variance, from which the adequacy of the model was deduced to explain the correlational matrix. The variance explained by the six-dimensional solution was estimated at $55.89 \%$, sufficient for the purposes of subsequent analyzes.

The solution was rotated initially with Varimax, but the resulting factor score distributions in the factors that were shown to be reliable correlated significantly with some intensity, which led to the rethinking of the initial decision and the adoption of an oblique rotation method (Oblimin with Kaiser normalization [delta $=0$ ]). The rotated model is presented in Table 2, which shows the saturations of the items in the factors.

The regression method was used to obtain an estimate of the factorial scores, verifying a high correlation between the factors 1 and $2(r=.510, p<.001)$; moderate between the factors: 1 and $6(r=.429, p<.001), 3$ and $5(r=.352, p<.001), 2$ and $6(r=.342, p<$ $.001), 4$ and $5(r=.321, p<.001)$; and light among the factors: 2 and $4(r=.296, p<.001), 2$ and $3(r=.274, p<.001), 2$ and $5(r=.216, p<.001), 3$ and $4(r=.184, p=.001), 1$ and $5(r=$ $.159, p=.003) \mathrm{y}, 1$ and $4(r=.154, p=.005)$. 
Table 2. Rotated configuration matrix. Attributions regarding repetitions

\begin{tabular}{|c|c|c|c|c|c|c|}
\hline \multirow{2}{*}{ Items } & \multicolumn{6}{|c|}{ Factors } \\
\hline & 1 & 2 & 3 & 4 & 5 & 6 \\
\hline 47. I was not integrated into the new class, it was not "my group" & .754 & .007 & .126 & -.030 & .008 & .121 \\
\hline 57. I felt rejection from classmates & .743 & .250 & -.089 & -.082 & -.030 & .070 \\
\hline 55. I felt unfairly discriminated against & .707 & .191 & .034 & -.088 & -.048 & .230 \\
\hline 53. They "gifted me" some passing scores & .568 & .083 & .084 & .175 & -.065 & -.113 \\
\hline 65. I was not going to pass ESO for reasons beyond my control & .446 & .253 & -.082 & .220 & .159 & .331 \\
\hline 63. I was not going to pass ESO for personal reasons & .423 & .124 & -.052 & .192 & .125 & .363 \\
\hline 60. I liked having reinforcement in different subjects & .127 & .689 & -.155 & -.100 & .210 & -.027 \\
\hline 59. My effort was not valued & .283 & .674 & .073 & .177 & -.003 & .090 \\
\hline 56. They suspended me for no reason & .214 & .543 & .194 & .226 & -.324 & .134 \\
\hline 52. The teachers weren't trying to get to know me & .262 & .542 & .316 & .036 & .094 & .220 \\
\hline 54. What I was studying was not useful & -.012 & .497 & .371 & .083 & .066 & .327 \\
\hline 46. There were too many study subjects during the same course & -.086 & .235 & .763 & -.039 & -.076 & .058 \\
\hline 45. There were too many teachers for the same course & .203 & .101 & .702 & .037 & .229 & -.015 \\
\hline 44. I did not follow the explanations and classes well & .027 & -.191 & .647 & .189 & .274 & -.126 \\
\hline 64. I was expelled from the center on some occasion & -.009 & .017 & -.052 & .785 & -.040 & .128 \\
\hline 61. I was punished on some occasion for no reason & .075 & .472 & .089 & .608 & .085 & -.195 \\
\hline 58. I was indifferent to the course. I did not care about anything & .059 & .012 & .240 & .605 & .275 & .167 \\
\hline 50. I didn't try hard enough & -.041 & .001 & .114 & .049 & .817 & .082 \\
\hline 49. I was bored studying & -.153 & .102 & .327 & .289 & .604 & -.107 \\
\hline 51. I felt like "the repeater" & .365 & .266 & .077 & -.027 & .454 & .058 \\
\hline 62. I changed schools during my studies to improve & .001 & .186 & .007 & .131 & -.048 & .789 \\
\hline 48. I had no support from my family & .321 & -.032 & -.008 & -.042 & .033 & .606 \\
\hline Explained variance & 12.95 & 10.87 & 9.24 & 7.85 & 7.57 & 7.37 \\
\hline
\end{tabular}

${ }^{1}$ The highest saturations of the items in each factor are highlighted in bold.

Based on the content of the items that are most significant in each factor, the following interpretation was reached:

a) Factor 1: Lack of integration and non-improvement (IS). Refers to the lack of integration of the student into the class group, discrimination and rejection $(47,55$ and 57$)$, and the belief that they will not successfully complete ESO $(53,63$ y 65).

b) Factor 2: Externalization of failure (EF). These items (52, 54, 56, 59 and 60) refer to external causes for being held back, such as the lack of usefulness of the lessons, underestimation of the student's effort or the lack of interest of the teachers.

c) Factor 3: Multiplicity of resources making learning difficult (MR). Considers the large number of teachers and subjects to study during ESO and the difficulty in following the explanations and the classes $(44,45$ and 46).

d) Factor 4: Disruptive behavior and indifference (DB). This category groups together the consequences of inappropriate behaviors in the classroom and apathy towards studies (58, 61 and 64).

e) Factor 5: Internalization of failure (IF). Alludes to lack of effort and repeater labeling (49, 50 and 51), showing intrinsic causes.

f) Factor 6: Change of center without support (CA). Refers to the lack of family support and the search for improvements through a change of educational center (48 and 62).

Once the structure of the construct was explained, the internal consistency was calculated. The reliability coefficients in the six factors (Cronbach's Alpha) were .735, .714, 
$.603, .556, .505$ and .404 , following the order. The internal consistency of the construct is adequate in the first two factors, so its use is maintained for critical analyzes, although successive factors were rejected.

Considering the reliable factors and the high correlation between them, which show the existence and association of several factors used to explain repetition during ESO, it was decided to use these two dependent variables in later analyses: Lack of integration and non-improvement (IS) and Externalization of failure (EF).

The results recorded describing each of the latent variables are presented below. The following table (Table 3) shows that the students do not agree with much regarding the lack of integration and failure to pass (IS), with a mean of $2.18(\mathrm{~N}=341)$ and a cumulative response percentage of $56.7 \%$. The students have not felt discrimination or rejection from other classmates, nor have they felt different from the group. Nor do they believe that the teachers have "gifted" them passing grades. Likewise, students show little agreement regarding the externalization of failure $(\mathrm{EF})$, with a total mean of $2.60(\mathrm{~N}=$ $342,53.8 \%$ ). This indicates that students believed that the teaching staff was interested in getting to know them. Even though they failed, this effort was valued.

Table 3. Response according to repetition in previous stages

\begin{tabular}{|c|c|c|c|}
\hline & $\mathbf{M}$ & DT & $\mathbf{N}$ \\
\hline \multicolumn{4}{|l|}{ Factor 1: Lack of integration and non-improvement (IS) } \\
\hline 47. I was not integrated into the new class, it was not "my group" & 2.39 & 1.49 & 337 \\
\hline 55. I felt unfairly discriminated against & 1.95 & 1.34 & 336 \\
\hline 57. I felt rejection from classmates & 2.06 & 1.42 & 338 \\
\hline 53. They "gifted me" some passing scores & 1.91 & 1.31 & 337 \\
\hline 63. I was not going to pass ESO for personal reasons & 2.31 & 1.45 & 337 \\
\hline 65. I was not going to pass ESO for reasons beyond my control & 2.42 & 1.50 & 334 \\
\hline Total: & 2.18 & .93 & 341 \\
\hline \multicolumn{4}{|l|}{ Factor 2: Externalization of failure (EF) } \\
\hline 52. The teachers weren't trying to get to know me & 2.59 & 1.47 & 336 \\
\hline 54. What I was studying was not useful & 2.67 & 1.46 & 335 \\
\hline 56. They suspended me for no reason & 2.23 & 1.42 & 335 \\
\hline 59. My effort was not valued & 2.67 & 1.50 & 335 \\
\hline 60. I liked having reinforcement in different subjects & 2.85 & 1.48 & 327 \\
\hline Total: & 2.60 & 1.00 & 342 \\
\hline
\end{tabular}

\subsection{Current educational interest}

In order to find the benefit that students obtain by taking BPT, the following variables have been considered: interest in academic-professional training, only professional interest, only academic interest, lack of interest. To analyze the differences, repeated ANOVA measures were completed with the four intra-subject variables (Table 4). Significant differences affecting the sample group have been found for all current educational interest variables $(F[3,945]=151.95, p<.0001, \varepsilon 2=.325)$. 
Table 4. Intrasubject differences regarding their educational interest

\begin{tabular}{|c|c|c|c|c|c|c|}
\hline \multirow[b]{2}{*}{ (I) factor1 } & \multirow[b]{2}{*}{$(\mathrm{J})$ factor1 } & \multirow{2}{*}{$\begin{array}{c}\text { Difference } \\
\text { of means (I- } \\
\mathrm{J} \text { ) }\end{array}$} & \multirow[b]{2}{*}{$\begin{array}{c}\text { standard } \\
\text { Error }\end{array}$} & \multirow[b]{2}{*}{ Sig. ${ }^{b}$} & \multicolumn{2}{|c|}{$\begin{array}{c}95 \% \text { confidence } \\
\text { interval for } \\
\text { difference }^{b} \\
\end{array}$} \\
\hline & & & & & $\begin{array}{l}\text { Lower } \\
\text { limit }\end{array}$ & $\begin{array}{l}\text { higher } \\
\text { limit }\end{array}$ \\
\hline \multirow{3}{*}{$\begin{array}{l}\text { Academic and } \\
\text { professional }\end{array}$} & Professional & $.766^{*}$ & .122 & .000 & .526 & 1.006 \\
\hline & Académico & $1.532^{*}$ & .105 & .000 & 1.324 & 1.739 \\
\hline & Ninguno & $2.044^{*}$ & .109 & .000 & 1.830 & 2.259 \\
\hline \multirow[t]{3}{*}{ Academic } & Academic and professional & $-.766^{*}$ & .122 & .000 & -1.006 & -.526 \\
\hline & Academic & $.766^{*}$ & .093 & .000 & .582 & .950 \\
\hline & None & $1.278^{*}$ & .096 & .000 & 1.089 & 1.468 \\
\hline \multirow[t]{3}{*}{ Academic } & Academic and professional & $-1.532^{*}$ & .105 & .000 & -1.739 & -1.324 \\
\hline & Professional & $-.766^{*}$ & .093 & .000 & -.950 & -.582 \\
\hline & None & $.513^{*}$ & .085 & .000 & .345 & .680 \\
\hline \multirow[t]{3}{*}{ None } & Academic and professional & $-2.044^{*}$ & .109 & .000 & -2.259 & -1.830 \\
\hline & Professional & $-1.278^{*}$ & .096 & .000 & -1.468 & -1.089 \\
\hline & Academic & $-.513^{*}$ & .085 & .000 & -.680 & -.345 \\
\hline
\end{tabular}

$1 p<.05$.

2 Adjustment for multiple comparisons: least significant difference (equivalent to no adjustments).

The union of academic and professional training is valued by almost half of the students surveyed $(41.8 \%, \mathrm{n}=141)$, with an average response of $3.8585(\mathrm{~N}=316)$. As can be seen in figure 1, the students do not agree at all that they are only interested in academic training $(\mathrm{n}=126,38.3 \%)$, with professional training being the most valued. The lowest mean of response refers to lack of interest $(\mathrm{M}=1.81)$.

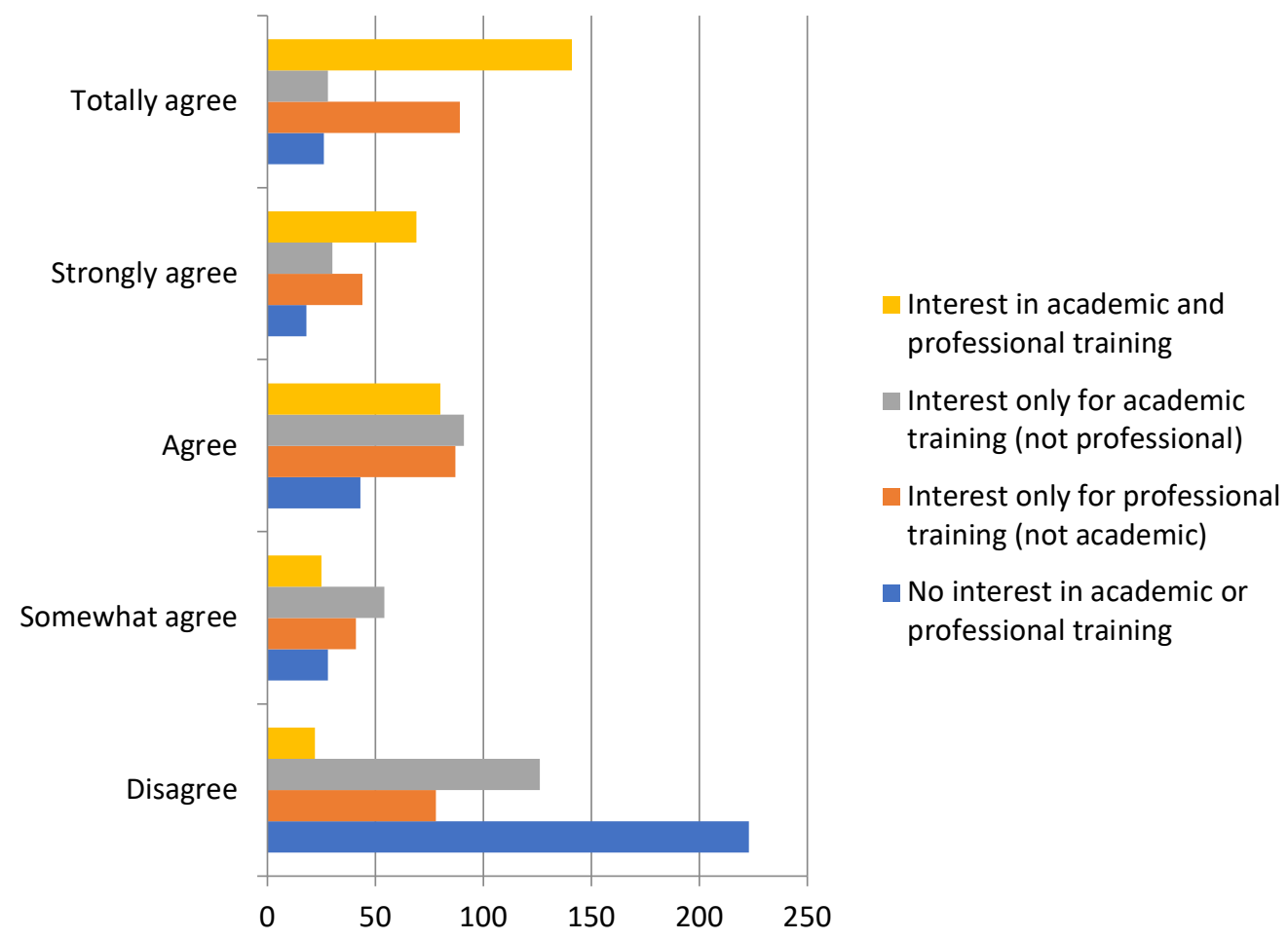

Figure 1. Interest in academic and professional training 


\subsection{Satisfaction shown with respect to BPT}

An exploratory factor analysis was carried out using principal component analysis. Bartlett's sphericity test showed a significant difference between the empirical correlation matrix and the identity matrix $\left(x^{2}[153]=2197.633, p<.001\right)$, which made it possible to continue with factor extraction. Moreover, the Kaiser-Meyer-Olkin measure of sampling adequacy reported an adequate degree of common variance between the items $(\mathrm{KMO}=.925)$.

The extraction of factors was forced to two, since this yields a more uniform and adequate solution to explain the correlational matrix. The variance explained by the three-dimensional solution was found to be $49.32 \%$, acceptable for the purposes of subsequent analyzes. As in the previous exploratory factor analysis, an oblique rotation method was adopted (Oblimin with Kaiser normalization [delta $=0$ ]), shown in Table 5. The regression method was used to obtain an estimate of the factor scores, verifying high correlations between the factors 1 and $2(r=-.614, p<.001)$.

Table 5. Rotated configuration matrix. Student satisfaction

\begin{tabular}{|l|c|c|}
\hline \multicolumn{1}{|c|}{ Items } & \multicolumn{2}{c|}{ Factors } \\
\cline { 2 - 3 } & \multicolumn{1}{|c|}{} \\
\hline 99. The teachers know me a lot, they care about me & .858 & .205 \\
\hline 100. The Cycle is more relaxed, it gives me time to learn & .669 & -.123 \\
\hline 98. I value having fewer teachers per course & .631 & .102 \\
\hline 108. Studying a Cycle improves my self-esteem & .622 & -.188 \\
\hline 97. The teachers facilitate my study. they are colleagues & .611 & -.096 \\
\hline 105. I have good classmates and that helps me & .560 & -.110 \\
\hline 107. Studying a Cycle is useful & .523 & -.244 \\
\hline 109. Studying a Cycle helps me with my family & .487 & -.152 \\
\hline 96. I feel like part of the class and they pay attention to me & .440 & -.347 \\
\hline 106. If I don't understand something. they repeat it until I understand & .440 & -.287 \\
\hline 95. The teachers of the cycles help me & .381 & -.378 \\
\hline 102. I'm better in the Cycle than in the ESO & -.176 & -.887 \\
\hline 104. I come to class excited. it's worth the effort & .068 & -.729 \\
\hline 94. This is the best thing that has happened to me in regard to my education & -.007 & -.728 \\
\hline 103. Now I am able to take on my own projects & .102 & -.703 \\
\hline 101. I come to class at ease. happy & .162 &.- .656 \\
\hline 110. My attitude has improved & .155 & -.572 \\
\hline 111. I think I will pass the Cycle without problem & .081 & -.560 \\
\hline Explained variance & 42.93 & 6.38 \\
\hline
\end{tabular}

${ }^{1}$ The highest saturations of the items in each factor are highlighted in bold.

Based on the content of the items that are most significant in each factor, the following interpretation was reached:

a) Factor 1: External support and adaptation to the cycle (AP). Refers to the help and proper number of teaching staff $(99,98,97,106$ and 95), help from classmates (105) and families (109), and the suitability of the cycle (100, 107, $96,108)$.

b) Factor 2: Empowerment and improvement of situation (EE). It highlights the student's positive attitude and enthusiasm for learning (104, 103, 101, 110, $111)$ and growth compared to previous studies $(102,94)$.

Once the structure of the construct was explained, the internal consistency was calculated. The reliability coefficients (Cronbach's Alpha) were .876 and .848 , respectively. The internal consistency of the construct is very strong in both factors, so its use is maintained for critical analyzes. Considering the reliable factors and the correlation between them, it was decided to use these two dependent variables in the subsequent analyses: 
External support and adaptation to the cycle (AP) and Empowerment and improvement of situation (EE).

Table 6. Student satisfaction with the BPT cycles

\begin{tabular}{|c|c|c|c|}
\hline & $\mathrm{M}$ & DT & $\mathrm{N}$ \\
\hline \multicolumn{4}{|l|}{ Factor 1: External support and adaptation to the cycle (AP) } \\
\hline 99. The teachers know me a lot. they care about me & 3.66 & 1.16 & 331 \\
\hline 100. The Cycle is more relaxed. it gives me time to learn & 4.00 & 1.11 & 331 \\
\hline 98. I value having fewer teachers per course & 3.95 & 1.16 & 326 \\
\hline 108. Studying a Cycle improves my self-esteem & 3.84 & 1.19 & 326 \\
\hline 97. The teachers facilitate my study. they are colleagues & 3.81 & 1.18 & 333 \\
\hline 105. I have good classmates and that helps me & 3.97 & 1.15 & 332 \\
\hline 107. Studying a Cycle is useful & 4.15 & 1.09 & 330 \\
\hline 109. Studying a Cycle helps me with my family & 3.73 & 1.22 & 329 \\
\hline 96. I feel like part of the class and they pay attention to me & 4.05 & 1.15 & 332 \\
\hline 106. If I don't understand something. they repeat it until I understand & 4.04 & 1.13 & 330 \\
\hline 95. The teachers of the cycles help me & 3.86 & 1.16 & 331 \\
\hline Total & 3.90 & 1.15 & 335 \\
\hline \multicolumn{4}{|l|}{ Factor 2: Empowerment and improvement of situation (EE). } \\
\hline 102. I'm better in the Cycle than in the ESO & 4.22 & 1.20 & 327 \\
\hline 104. I come to class excited. it's worth the effort & 4.08 & 1.04 & 328 \\
\hline 94. This is the best thing that has happened to me in regard to my education & 3.80 & 1.26 & 329 \\
\hline 103. Now I am able to take on my own projects & 4.00 & 1.09 & 334 \\
\hline 101. I come to class at ease. happy & 3.95 & 1.13 & 328 \\
\hline 110. My attitude has improved & 4.03 & 1.17 & 328 \\
\hline 111. I think I will pass the Cycle without problem & 4.05 & 1.08 & 331 \\
\hline Total & 4.01 & 1.13 & 335 \\
\hline
\end{tabular}

After the descriptive analysis (Table 6), a high degree of agreement can be observed regarding the satisfaction given to external support and the adequacy of the cycle $(\mathrm{M}=$ $3.90, \mathrm{~N}=335)$. Likewise, the group is quite in agreement with the value placed on empowerment and the improvement of the situation $(\mathrm{M}=4.01, \mathrm{~N}=335)$.

One hypothesis is that the specialty influences the students' degree of satisfaction regarding the development of the studies carried out. In order to verify this, we have proceeded to analyze variance of a factor $($ n.s. $=0.05)$.

The AP and EE variables have been considered. Levene's test for homogeneity of variances shows values greater than .05 in the two variables: $\operatorname{AP}(F[3.331]=.143, p=$ $.934)$ and $\operatorname{EE}(F[3.331]=.237, p=.870)$. As can be seen in table 7 , after the ANOVA measure of one factor, it clear that there are significant differences in the scoring $\mathrm{AP}(F=$ 2.636; $p=.050, \varepsilon 2=.023)$ since there are no differences in EE by sectors $(F=1.032 ; p=.379$, $\varepsilon 2=.009)$. Because a very specific difference is detected, we reject the idea that the specialty influences the students' degree of satisfaction regarding the development of their studies, which is very high in all sectors. 
Table 7. Differences in the degree of satisfaction by sectors

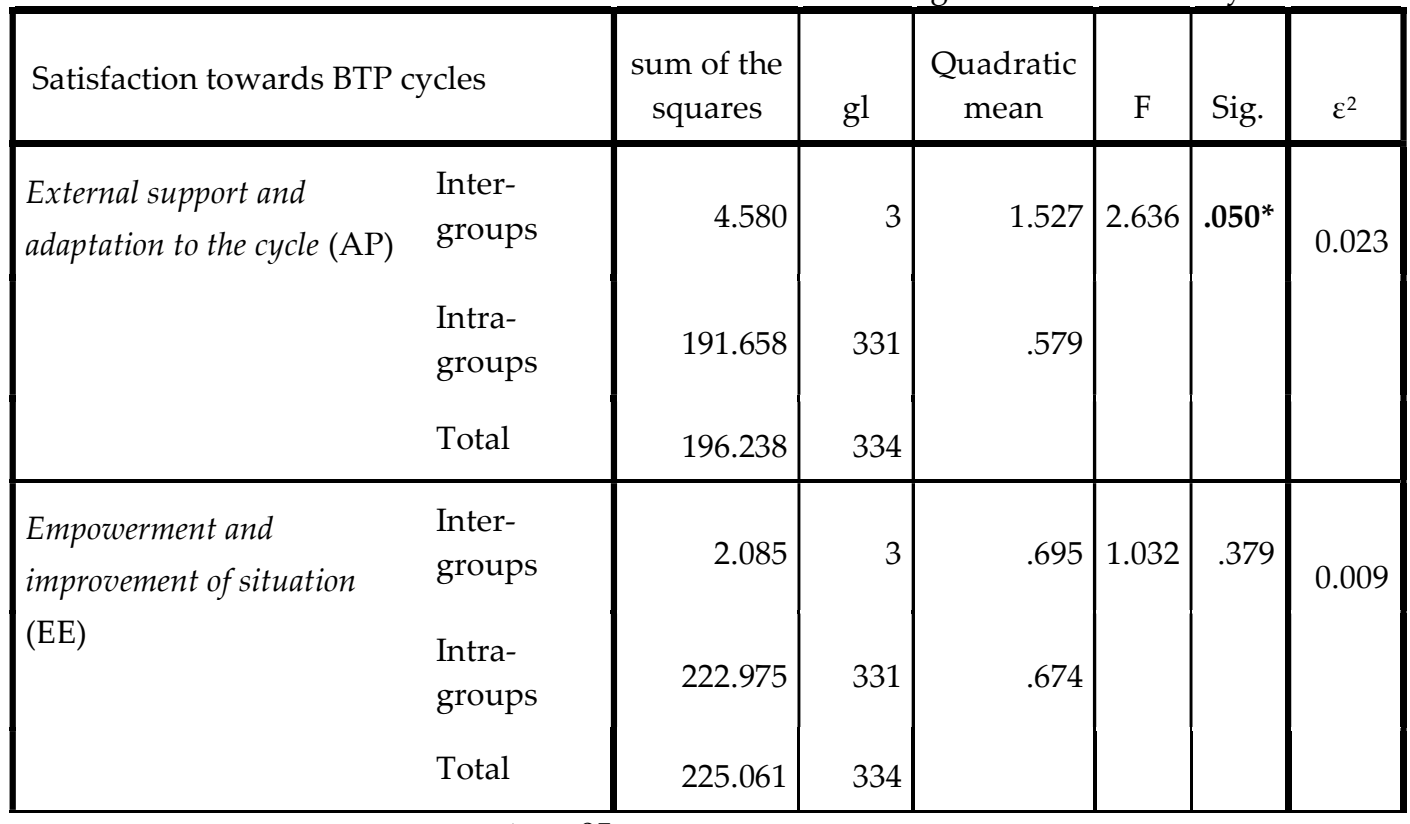

${ }^{1} p<.05$.

\subsection{Goals after finishing the BPT cycle}

An exploratory factor analysis was carried out. Item 120 ("I have not thought about it yet") was eliminated when it was found that it did not contribute to the reliability of the instrument, which increases up to.762 using the remaining items. Bartlett's sphericity test showed a significant difference between the empirical correlation matrix and the challenges or expectations after BPT matrix $\left(x^{2}[28]=585.50, p<.001\right)$, which made it possible to continue with factor extraction. Likewise, the Kaiser-Meyer-Olkin measure of sampling adequacy reported an adequate degree of common variance between the items $(\mathrm{KMO}=.790)$.

The criterion of an eigenvalue greater than 1 was used since it gave a solution of two similar factors. The variance explained by the two-dimensional solution was estimated at $54.14 \%$, sufficient for the purposes of subsequent analyzes. The solution was rotated with Varimax. The rotated model is presented in Table 8, which shows the saturations of the items in the factors. The regression method was used to obtain an estimate of the factorial scores, verifying a moderate correlation between the two factors $(r=.371$, $p<.001)$, therefore the adopted criterion was maintained.

Table 8. Rotated configuration matrix. Student goals

\begin{tabular}{|l|r|r|}
\hline \multicolumn{1}{|c|}{ Items } & \multicolumn{2}{|c|}{ Factors } \\
\cline { 2 - 3 } & \multicolumn{1}{|c|}{. } & \multicolumn{1}{|c|}{} \\
\hline 113. I want to join the working world & .712 \\
119. I want to be useful to society & .708 \\
115. I want them to be proud of me & .670 \\
114. I want to become professionally qualified & .666 \\
112. I would like to be able to do a Middle Grade Cycle & .583 \\
117. I want to get the ESO Diploma & .581 \\
118. I want to get a higher or university degree & .227 \\
116. I want to continue studying & .036 \\
\hline Explained variance & .297 \\
\hline
\end{tabular}


${ }^{1}$ The highest saturations of the items in each factor are highlighted in bold.

Based on the content of the items that are most significant in each factor, the following interpretation was reached:

a) Factor 1: Socio-professional and intermediate academic levels goals (MP). Referring to short and medium term goals at a professional and academic level, basic and middle studies, it adds social purposes $(112,113,114,115,117$, 119).

b) Factor 2: Long-term academic goals (LP). Wanting to do university or higher education and the desire to continue studying in the long term converge (116 and 118).

After reviewing the structure of the construct, the internal consistency was calculated. The reliability coefficients in the two factors (Cronbach's Alpha) were .765 and .574, respectively. As only the first case was adequate, only this variable is kept for use in critical analyzes: Socio-professional and intermediate academic levels goals (MP).

In a descriptive analysis, it is clear how students highly value socio-professional goals and medium academic levels, giving higher values to wanting to obtain an ESO Diploma (Table 9).

Table 9. Student satisfaction with the BPT cycles

\begin{tabular}{|c|c|c|c|}
\hline & M & DT & $\mathrm{N}$ \\
\hline \multicolumn{4}{|l|}{$\begin{array}{c}\text { Factor 1: Socio-professional and intermediate academic } \\
\text { levels goals (MP). }\end{array}$} \\
\hline 112. I would like to be able to do a Middle Grade Cycle & 3.97 & 1.34 & 332 \\
\hline 113. I want to join the working world & 4.04 & 1.23 & 327 \\
\hline 114. I want to become professionally qualified & 4.19 & 1.03 & 327 \\
\hline 115. I want them to be proud of me & 4.29 & 1.12 & 331 \\
\hline 117. I want to get the ESO Diploma & 4.37 & 1.09 & 332 \\
\hline 119. I want to be useful to society & 4.18 & 1.10 & 332 \\
\hline Total & 4.17 & 1.15 & 332 \\
\hline
\end{tabular}

Next, we analyze the hypothesis that the appearance of socio-professional goals and average academic levels is influenced by the attributions of the students with regard to the repetition of previous courses. The MP variable and the IS and EF variables have been taken into account. After performing the Pearson correlation $(r)$, no significance is detected at level .01 (bilateral) between MP and IS $(r=.036, p=.515)$, nor with EF $(r=$ $.002, p=.976)$. These are very low or null relationships that cannot confirm the hypothesis raised. Considering both the lack of student integration and discrimination and rejection (IS), as well as the external causes for which the student could have repeated prior grades (EF), the data indicated that students did not necessarily agree with these attributions ( $\mathrm{M}=2.18$ y 2.60 , respectively).

With the hypothesis that the socio-professional goals and average academic levels vary depending on the satisfaction shown by the students with respect to the BPT cycles, the MP variable and the AP and EE variables have been taken into account. Using Pearson's correlation $(r)$, significance is detected at the 0.01 level (bilateral) with a moderate relationship between MP and $\operatorname{AP}(r=.569, p<.001)$ and $\operatorname{EE~}(r=522, p=<.001)$. In this manner, we can indeed affirm that the goals that the students set after completing BPT are related to their satisfaction when taking these cycles.

\section{Discussion}

We rely on the results of research [50-52], since not all students without an ESO Diploma are the same and their various itineraries are different from one another. The at- 
tributions that the students have chosen with respect to the repetition of previous courses are not linked to the lack of integration and failure to pass, nor to the externalization of failure.

On the other hand, the students value the academic-professional nature of the cycles and make us question whether these cycles really offer the opportunity to reengage.

The UNDP [26] warned of the vulnerability of young people without studies, who can improve their social and professional development and their educational opportunities through BPT, as well as their perception, self-esteem, motivation and responsibility, resulting in improvement in the level inclusion in labor and educational contexts [40, 43, 45, 53]. This possibility is affirmed. We conclude that the Basic Professional Training course influences the adoption of decisions regarding academic-professional projects. Prior studies pointed to such a relationship [53]. More than a few authors speak about turning BPT into a measure capable of intervening on the socialization and work identity of students $[45,47,52,54,55]$.

\section{Conclusions}

We are committed to an inclusive education based on welcoming students who do not wish to enroll in a closed and inflexible system. This research is the result of the decisions adopted in educational policy, which leads to reflection. We recommend a flexible, inclusive BPT, guaranteeing equal opportunities. It would be interesting to inquire about the manner in which BPT and Secondary school teachers conceive of inclusion.

It is advisable that the main objective of the reforms is to facilitate students' educational success, defined by inclusion and equity [56]. Creating itineraries at an early age can generate school objectors, failure and school dropout. An educational system that allows students to disengage maintains and generates social inequalities, promotes precarious jobs and social exclusion. As an alternative, we propose that this question continue to be investigated, seeking less devastating alternatives than those of previous policies, striving for solutions that are transdisciplinary, eco-forming and sustainable.

Perhaps it would be convenient for these cycles to find room for intervention, and to provide young people with the appropriate resources when and how they need them to handle the deprivation, vulnerability and exclusion they are going through, as opposed to other forms of integration which stops and corrects their deterioration trajectories. This may be an appropriate response, capable of affecting the socialization and work identity of young people, as proposed by various authors. It is proposed that we follow this proposal and generate research regarding social inclusion.

The latest educational laws being implemented are modifying the BPT provide an uncertain future. According to Edgar Morin [57], in the face of such continuous changes, it will be appropriate to propose a paradigmatic and non-programmatic change in thinking in order to confront the education of the future and the increasingly broad, deep and serious inadequacy which lies between our knowledge and the increasingly polydisciplinary, multidimensional, transnational, global and planetary realities.

Author Contributions: Each author has contributed equally to all aspects of this research. All authors have read and agreed to the published version of the manuscript.

Funding: This research received no external funding.

Data Availability Statement: The data presented in this study are available upon request from the corresponding author.

Acknowledgments: The support received by the centers participating in this study is appreciated.

Conflicts of Interest: The authors declare no conflict of interest. 


\section{References}

1. Merino, R.; García, M.; Casal, J. De los Programas de Garantía Social a los Programas de Cualificación Profesional Inicial. Sobre perfiles y dispositivos locales. Revista de Educación 2006, 81-98. Available online: http://www.revistaeducacion.educacion.es/re341/re341 04.pdf (accessed on 27 July 2021).

2. Santos Rego, M.A; Lorenzo Moledo, M.; Vázquez Rodríguez, A. Educación no formal y Empleabilidad de la juventud. Síntesis, Madrid, 2018.

3. Helms Jørgensen, C. Tres concepciones de las relaciones cambiantes entre la educación y el trabajo. En Las políticas de formación profesional en España y en Europa: perspectivas comparadas; A. Luzón y M. Torres (Comps.). Octaedro, Barcelona, España, 2014; pp. 27-48.

4. Santos Rego, M.A.; Ferraces, M.J.; Mella, I.; Vázquez Rodríguez, A. Universidad, competencias cívico-sociales y mercado laboral. Revista Española de Pedagogía 2020, 78 (276) pp. 213-232. DOI: https://doi.org/10.22550/REP78-2-2020-06

5. Campaña-Jiménez, R.L.; Gallego-Arrufat, M.J.; Muñoz-Leiva, F. Estrategias de enseñanza para la adquisición de competencias en formación profesional: Perfiles de estudiantes. Educar 2019, 55(1), pp. 203-229.

6. MEFP. Igualdad en cifras. MEFP 2020: Aulas por la igualdad. Ministerio de Educación y Formación Profesional. Madrid, 2020.

7. Martínez-Carmona, M. J.; Gil Del Pino, C.; Álvarez-Castillo, J. L. Análisis de los Programas de Cualificación Profesional Inicial (PCPI), más allá de las trayectorias fallidas. Revista de Pedagogía 2016, Vol. 37 (101), pp. 81-100. Available online: http://saber.ucv.ve/ojs/index.php/rev_ped/article/view/12502 (accessed on 27 July 2021).

8. Sarceda-Gorgoso, M.C.; Santos-González, M.C.; Sanjuán Roca, M.M. La Formación Profesional Básica: ¿alternativa al fracaso escolar? Revista de Educación 2017, 378, pp. 78-112. DOI: https://doi.org/10.4438/1988-592X-RE-2017-378-362

9. Sarceda-Gorgoso, M. C.; Barreira-Cerqueiras, E. M. La Formación Profesional Básica y su contribución al desarollo de competencias para el reenganche educativo y la inserción laboral: percepción del alumnado. Educar 2021, 57(2), pp. 319-332.

10. INCUAL Catálogo Nacional de Cualificaciones Profesionales. Ministerio de Educación, Cultura y Deporte España, 2016. Available online: https://www.educacion.gob.es/educa/incual/ice catalogoWeb.html (accessed on 27 July 2021).

11. INCUAL. Sistema de cualificaciones como puentes para el aprendizaje a lo largo de toda la vida. Ministerio de Educación, por acuerdo con la OCDE, París, $2008 . \quad$ Available online: http://www.educacion.gob.es/educa/incual/pdf/2/00 OCDE COMPLETO Internet.pdf (accessed on 27 July 2021).

12. INCUAL Catálogo Nacional de Cualificaciones Profesionales (CNCP). Secretaría General Técnica, Madrid, 2008. Available online: http://www.educacion.gob.es/educa/incual/ice_catalogoWeb.html (accessed on 27 July 2021)

13. Cedefop. Mercado de trabajo global, formación profesional global. CEDEFOP, Madrid, 2015.

14. MECD. Datos y cifras. Curso escolar 2016-2017. Secretaría General Técnica, España, $2016 . \quad$ Available online: https://sede.educacion.gob.es/publiventa/datos-y-cifras-curso-escolar-20162017/ensenanza-estadisticas/21325 (accessed on 27 July 2021).

15. MEFP. Datos y cifras. Curso escolar 2020-2021. Secretaría General Técnica, España, 2020. Available online: https://www.educacionyfp.gob.es/dam/jcr:89c1ad58-80d8-4d8d-94d7-a7bace3683cb/datosycifras2021esp.pdf (accessed on 27 July 2021).

16. MECD. Portal todo FP (en línea). Available online: http://www.todofp.es/todofp (accessed on 27 July 2021).

17. LEY ORGÁNICA 8/2013, de 9 de diciembre, para la mejora de la calidad educativa (LOMCE). BOE, 295, 10/12/2013, 9785897921.

18. REAL DECRETO 694/2017, de 3 de julio, por el que se desarrolla la Ley 30/2015, de 9 de septiembre, por la que se regula el Sistema de Formación Profesional para el Empleo en el ámbito laboral (BOE 05-07-2017).

19. REAL DECRETO 127/2014, de 28 de febrero, por el que se regulan aspectos específicos de la Formación Profesional Básica de las enseñanzas de formación profesional del sistema educativo, se aprueban catorce títulos profesionales básicos, se fijan sus currículos básicos y se modifica el Real Decreto 1850/2009, de 4 de diciembre, sobre expedición de títulos académicos y profesionales correspondientes a las enseñanzas establecidas en la Ley Orgánica 2/2006, de 3 de mayo, de Educación (BOE 05-032014).

20. Helms Jørgensen, C. Tres concepciones de las relaciones cambiantes entre la educación y el trabajo. In Las políticas de formación profesional en España y en Europa: perspectivas comparadas; Luzón, A.; Torres, M. (Comps.); Octaedro, Barcelona, España, 2014, pp. 27-48.

21. Abril, A.; Ariza, M. R.; Quesada, A.; García, F. J. Creencias del profesorado en ejercicio y en formación sobre el aprendizaje por investigación. Revista Eureka sobre enseñanza y divulgación de las Ciencias, 2014, 11(1). Available online: http://www.redalyc.org/html/920/92029560004/ (accessed on 27 July 2021).

22. Harvey, A. C. Forecasting, structural time series models and the Kalman filter. Cambridge university press, Reino Unido, 1990.

23. Womack, J. P.; Jones, D. T.; Roos, D. Machine that changed the world. Simon and Schuster, New York, 1990.

24. Ley Orgánica 5/2002, de 19 de junio, de las Cualificaciones y de la Formación Profesional. BOE, 147, 20/06/2002, 22437 - 22442. [Texto Consolidado. Última modificación: 30/12/2020].

25. Durkheim, E. Education and Sociology. Les Presses universitaires de France, Paris, 1956.

26. PNUD. Informe sobre Desarrollo Humano 2014. Sostener el progreso humano: reducir vulnerabilidades y construir resiliencia. Programa de las Naciones Unidas para el Desarrollo (PNUD), Nueva York, $2014 . \quad$ Available online: http://www.undp.org/content/dam/undp/library/corporate/HDR/2014HDR/HDR-2014-Spanish.pdf (accessed on 27 July 2021). 
27. Pais, J.M. Laberintos de vida: paro juvenil y rutas de salida (jóvenes portugueses). Revista de Juventud, 2002, 56, pp. 87-101. Available online: https://s3.amazonaws.com/academia.edu.documents/39242715/2002_Estudios_de_juventud_56.pdf?AWSAccessKeyId=AKIAI WOWYYGZ2Y53UL3A\&Expires=1502908148\&Signature=h4wG\%2BQKCG94qKry29UKeGvdeypA\%3D\&response-contentdisposition=inline \%3B\%20filename\%3DLaberintos de vida paro juvenil y rutas.pdf (accessed on 27 July 2021).

28. Walther, A.; Stauber, B; et al (eds) Misleading Trajectories - integration policies for young adults in Europe?. LeskeBudrich, Opladen, 2002.

29. Fernández-García, A.; García, J.L.; García, M. La formación profesional básica, una alternativa para atender las necesidades educativas de los jóvenes en riesgo social. Revista de Humanidades, 2019, 36, pp. $211-232 . \quad$ DOI https://doi.org/10.5944/rdh.36.2019.22564

30. Escarbajal Frutos, A.; Essomba Gelabert, M.; Abenza Pastor, B. El rendimiento académico de alumnos de la ESO en un contexto vulnerable y multicultural. Educar, 2019, 55(1), pp. 79-99. Available online: https://raco.cat/index.php/Educar/article/view/348882 (accessed on 27 July 2021).

31. EGRIS. Misleading trajectories - transition dilemmas of young adults in Europe. Journal of Youth Studies, 2001, 4 (1), pp. 101118. DOI: https://doi.org/10.1080/13676260120028574

32. Jacinto, C. La escuela media. Reflexiones sobre la agenda de la inclusión social con calidad. II Foro Latinoamericano de Educación, La escuela media. Realidades y desafíos, Editorial Santillana, Buenos Aires, 2006.

33. Real, M. R.; Fernández, F. J. A. Percepciones del profesorado y alumnado del programa de cualificación profesional inicial (PCPI). Desarrollo del proceso de enseñanza-aprendizaje en programas de prevención del fracaso escolar en secundaria. Espiral. Cuadernos del profesorado, 2016, 9(18), pp. 3-15. DOI: http://dx.doi.org/10.25115/ecp.v9i18.1000

34. Santos Rego, M. A.; Lorenzo Moledo, M.; Vázquez Rodríguez, A. Educación no formal y Empleabilidad de la juventud. Síntesis, Madrid, 2018.

35. Sarceda-Gorgoso, M. C.; Santos-González, M. C.; Sanjuán Roca, M. D. Basic Vocational Training: an alternative to school failure? Revista de Educación 2017, 378, pp. 75-98. DOI: https://doi.org/10.4438/1988-592X-RE-2017-378-362

36. Escarbajal Frutos, A.; Essomba Gelabert, M.; Abenza Pastor, B. El rendimiento académico de alumnos de la ESO en un contexto vulnerable y multicultural. Educar, 2019, 55(1), pp. 79-99.DOI: https://doi.org/10.5565/rev/educar.967

37. Moreno-Guerrero, A .J.; Fuentes Cabrera, A.; López Belmonte, J. Las competencias digitales del alumnado de Formación Profesional Básica. Revista de Educación de la Universidad de Granada, 2019, 26, pp. 9-33. DOI http://doi.org/10.30827/reugra.v26i0.111

38. Lledó, A.; Arnáiz, P. Evaluación de las prácticas educativas del profesorado de los centros escolares: indicadores de mejora desde la educación inclusiva. REICE. Revista Iberoamericana sobre Calidad, Eficacia y Cambio en Educación, 2010, 8 (5), pp. 96-109. Available online: http://www.rinace.net/reice/numeros/arts/vol8num5/art6.pdf (accessed on 27 July 2021).

39. Arnaiz, P. Análisis de las medidas de atención a la diversidad en la Educación Secundaria Obligatoria. Revista de Educación, 2009, 349, pp. 203-233.

40. Aramendi, P.; Lizasoain, L.; Lukas, J.F. Organización y funcionamiento de los centros educativos de Formación Profesional Básica. Bordón, 2018, 70(2), pp. 9-23.

41. Brunet, I.; Pizzi, A.; Valls, F. Condiciones de vida y construcciones de identidades juveniles: El caso de los jóvenes pobres y excluidos en España. Revista Mexicana de Sociología, 2013, 75(4), 647-674. DOI: http://dx.doi.org/10.22201/iis.01882503p.2013.4.42271

42. Sarceda-Gorgoso, M. C.; Santos-González, M. C.; Barreira-Cerqueiras, E. M.; Sanjuán-Roca, M. M. Atención a la diversidad, éxito educativo y empleabilidad: De los programas de garantía social a la formación profesional básica. In Éxito educativo: Claves de construcción y Desarrollo; Santos Rego, M. A., Valle Arias, A., Lorenzo Moledo, M., Eds.; Tirant Lo Blanch, Valencia, 2019; pp. 255-272.

43. Olmos-Rueda, P.; Mas-Torelló, O. Perspectiva de tutores y de empresas sobre el desarrollo de las competencias básicas de empleabilidad en el marco de los programas de formación profesional básica. Educar 2017, 53(2), pp. 261-284. DOI: https://doi.org/10.5565/rev/educar.870

44. Amores Fernández, J.; Ritacco Real, M. De los Programas de Cualificación Profesional Inicial (PCPI) como medida de prevención del fracaso escolar a la Formación Profesional Básica: Un estudio sobre el éxito y fracaso de alumnos en riesgo de exclusión educativa en Educación Secundaria. Revista de Investigación en Educación 2015, 13(1), pp. 105-120. Available online: https://revistas.webs.uvigo.es/index.php/reined/article/view/2046 (accessed on 27 July 2021).

45. Olmos-Rueda, P.; Mas-Torelló, O. Jóvenes, fracaso escolar y programas de segunda oportunidad. Revista Española de Orientación y Psicopedagogía 2013, 24(1), pp. 78-93. DOI: https://doi.org/10.5944/reop.vol.24.num.1.2013.11272

46. Negri, M. I.; Leiva, J. J. Liderazgo de los docentes de formación profesional básica para la mediación escuela-empleo del alumnado con diversidad funcional intelectual. Contextos Educativos 2019, 24, pp. 95-111. DOI: http://doi.org/10.18172/con.3902

47. González-González, M. T.; Cutanda-López, M.T. Programas de Reenganche educativo y condiciones organizativas para su implementación: La importancia de la coordinación curricular. Educatio Siglo XXI 2020, 38(2), pp. 17-44. DOI: https://doi.org/10.6018/educatio.410721

48. Abiétar-López, M.; Navas-Saurin, A. A.; Marhuenda-Fluixá, F.; Salvà-Mut, F. La construcción de subjetividades en itinerarios de fracaso escolar: Itinerarios de inserción sociolaboral para adolescentes en riesgo. Psychosocial Intervention 2017, 26(1), pp. 3945. DOI: http://dx.doi.org/10.1016/j.psi.2016.07.002 
49. Martínez González, R. A. La investigación en la práctica educativa: guía metodológica de investigación para el diagnóstico y evaluación de los centros docentes. CIDE/MEC, Madrid, España, 2007.

50. Martínez Domínguez, B. Puentes entre el fracaso escolar y un nuevo escenario sociolaboral. Cuadernos de Pedagogía 2008 (382), pp. 67-69.

51. Martínez Domínguez, B. Luces y sombras de las medidas de atención a la diversidad en el camino de la inclusión educativa. Revista Interuniversitaria de Formación del profesorado 2011, 25(1), pp. 165-183. Available online: http://www.redalyc.org/pdf/274/27419147010.pdf (accessed on 27 July 2021).

52. Martínez, B.; Mendizábal, A.; Pérez-Sostoa, V. Una oportunidad para que los jóvenes que fracasan en la escuela puedan salir de la zona de riesgo de exclusión. La experiencia de los Centros de Iniciación Profesional en la Comunidad Autónoma Vasca. Profesorado, revista de currículum y formación del profesorado 2009, 13, (3), pp. 239-271. Available online: http://www.redalyc.org/pdf/567/56712871011.pdf (accessed on 27 July 2021).

53. Aramendi, P.; Vega, A.; Etxeberria, K. Los programas de atención a la diversidad en la Educación Secundaria desde la perspectiva de los estudiantes: estudio comparado. Revista de Educación 2011, 356, pp. 185-209.

54. Abdala, E.; Jacinto, C.; Solla, A. (coords.) La inclusión laboral de los jóvenes: entre la desesperanza y la construcción colectiva. Cinterfor/OIT, Montevideo, 2005.

55. Laparra, M.; Obradors, A.; Pérez Eransus, B.; Pérez-Yruela, M.; Renes, V.; Sarasa, S.; Subirats, J.; Trujillo, M. Una propuesta de consenso sobre el concepto de exclusión. Implicaciones Metodológicas. Revista Española del Tercer Sector 2007, 5, 15-58.

56. Gimeno Sacristán, J.; Rodríguez Martínez, C. (coords). Manifiesto: Por otra política educativa. Foro de Sevilla. Ediciones Morata Madrid, España, 2013.

57. Morin, E. Los siete saberes necesarios para la educación del futuro. UNESCO, Francia, 1999. 